\title{
The Effect of Returning Farmland to Grassland and Coniferous Forest on Watershed Runoff-A Case Study of the Naoli River Basin in Heilongjiang Province, China
}

\author{
Xuefeng Bai ${ }^{1,2}$, Bin Wang ${ }^{2, *}$ and Ying $Q i^{2,3, *}$ \\ 1 Institute of Natural Resources and Ecology, Heilongjiang Academy of Sciences, Harbin 150040, China; \\ baixuefeng@neau.edu.cn \\ 2 School of Water Conservancy and Civil Engineering, Northeast Agricultural University, Harbin 150030, China \\ 3 Heilongjiang Province Hydraulic Research Institute, Harbin 150080, China \\ * Correspondence: wangbin@neau.edu.cn (B.W.); qiying@neau.edu.cn (Y.Q.)
}

Citation: Bai, X.; Wang, B.; Qi, Y. The Effect of Returning Farmland to Grassland and Coniferous Forest on Watershed Runoff-A Case Study of the Naoli River Basin in Heilongjiang Province, China. Sustainability 2021, 13, 6264. https://doi.org/10.3390/ su13116264

Academic Editor: Hone-Jay Chu

Received: 2 April 2021

Accepted: 24 May 2021

Published: 1 June 2021

Publisher's Note: MDPI stays neutral with regard to jurisdictional claims in published maps and institutional affiliations.

Copyright: (C) 2021 by the authors Licensee MDPI, Basel, Switzerland. This article is an open access article distributed under the terms and conditions of the Creative Commons Attribution (CC BY) license (https:// creativecommons.org/licenses/by/ $4.0 /)$.

\begin{abstract}
In the 1950s and 1970s, China implemented large-scale wasteland reclamation in the Sanjiang Plain in eastern Heilongjiang Province, which expanded the area of cultivated land. Cultivated areas alter the quantity of water resources, provide the ecological requirements of river basins, and promote the ecological health of land use. In this study, the grid-based Sacramento (GSAC) model was adopted to simulate various changes in arable land, grassland, cultivated land, and deciduous coniferous forest. Quantitative analysis of the influence of cultivated land change on runoff and under dry season flow was conducted. The results showed that the GSAC model attains a high certainty coefficient in the process of simulating the daily basin discharge and reproduces the daily basin discharge process well for many years. The annual runoff increased between 5.07 and $64.05 \%$ due to the return of farmland to grassland and coniferous forest. The return of farmland to grassland greatly impacted runoff. The slope of the grassland and coniferous forest converted from farmland was negatively correlated with the discharge in the basin outlet section. The lower the gradient threshold in the scenario of returning arable land to forest or grassland, the more arable land will be replaced by grassland or deciduous coniferous forest, which could result in more water production in the watershed. Among the different change scenarios, the average flow rate of cultivated land with a slope larger than $15^{\circ}$ was the closest to the ecological water demand of the studied watershed. The land use mode of converting cultivated land with a slope larger than $15^{\circ}$ into grassland is expected to promote the ecological health of the watershed.
\end{abstract}

Keywords: land use/cover change; returning farmland to grassland; returning coniferous forests to cultivated land; the amount of runoff; ecological water requirements; the grid-based Sacramento model

\section{Introduction}

The study of land use/cover change (LUCC) is an important content in the field of earth surface science. Its impacts on the ecological environment mainly include climate [1-3], atmosphere [4], soil [5-7], hydrology [8-11], and biological [12,13] diversity. To better understand the effects of LUCC on the soil hydrological diversity at regional and global scales, research should focus on the assessment of the water cycle, ecological security patterns [10], relationship with ecological water requirements, and choices regarding land use in river basins. Therefore, in recent decades, research on the impact of LUCC on watershed-scale hydrology has become increasingly active.

The LUCC research methods of hydrological effects mainly include the test watershed method, characteristic variable time series method, and hydrological model method. However, due to the limitations of the first two methods $[14,15]$, research on hydrological models, especially distributed hydrological models [16], has become important. In 1969, 
Freeze and Harlan [17] first proposed the concept of a distributed hydrological model. In 1970, Onstad and Jamieson [18] evaluated LUCC hydrological effects with hydrological models. Gary W and Coutu et al. [19] employed the soil and water assessment tool (SWAT) and the Spearman rank correlation coefficient method to analyze the relationship between runoff changes and LUCC in the Brandie Wanxi watershed. Song Xuan et al. [20] applied the soil conservation service (SCS) hydrological model to study the long-term influence of LUCC on runoff in Lushan County. Ghaffari et al. [21] adopted the SWAT to simulate land use change in the Zanjan-rood basin, Iran, and examined the impact of land use change on surface runoff. In 2012, Niu Zuirong et al. [22] simulated the Qingyuan River watershed with the classified hydrological model. They reported the influence of LUCC on the annual runoff of this watershed on the Loess Plateau. Shi Xiaoliang et al. [23] also used the SWAT to evaluate the hydrological effects of LUCC on the Luan River Basin. Traditional hydrological models only reflect the impact of LUCC on hydrology at specific spatial scales such as hydrological response units and subcatchments, but it is difficult to reflect the impact of LUCC on hydrology at fine scales such as grids.

The spatial density of the hydrological station network in China is fairly low, and the established single-station observation areas of precipitation, runoff and evaporation are 500, 3202 , and $5800 \mathrm{~km}^{2}$, respectively [24]. Heilongjiang, the northernmost and coldest province in China, exhibits a low spatial density of its hydrological station network, including single-station control areas of precipitation, runoff, and evaporation phenomena of 902 , 4078 , and $7166 \mathrm{~km}^{2}$, respectively [25]. The type of precipitation in this area is rain, snow (from October to May) and/or a mixture of rain and snow. As a result, snow evaporation phenomena occur in this region, which inhibits the use of pan evaporation data collected during evaporation periods to estimate the potential evapotranspiration from all land cover types. The use of traditional hydrological models requiring high data integrity may not be applicable to watersheds with insufficient data (e.g., Heilongjiang Province, China).

In this paper, the land cover situation was studied in the watershed, policies and regulations on returning farmland to grassland or forest in China was obeyed, the topographic slope of the cultivated land was considered, and eight arable land variation scenarios were set, and the variation scenarios of "returning arable land to grass" and "returning arable land to forest" were set on a grid scale. A grid-based Sacramento (GSAC) model was used to simulate the hydrological effect of each grid and the daily discharge at the outlet of the watershed with different scenarios, and the simulated flow rate of the dry season was evaluated, to provide references for rational planning of land use, optimal allocation of water resources and assurance of ecological water demand in the alpine watershed in Heilongiiang Province.

\section{Watershed Study Overview}

The Naoli River is a tributary on the left bank of the Wusuli River in northeastern Heilongjiang Province, as shown in Figure 1. The stratigraphy of the study area is in the Xingkai Lake-Burea mountain zone. The main minerals in the outcropping layer are biotitehornblende-anorthose granulite, quartz schist and marble in the Dapandao Formation of the Proterozoic Xingdong Group [26]. There are mountains, hills and plains in the study area, and the terrain elevation decreases gradually from southwest to northeast. The cultivated soil types are black soil, meadow soil, and white clay soil. The thickness of the cultivated layer is over $25 \mathrm{~cm}$, the soil organic matter content is over $3 \%$, and the soil pH value is $6.3-7.0$ [27]. 


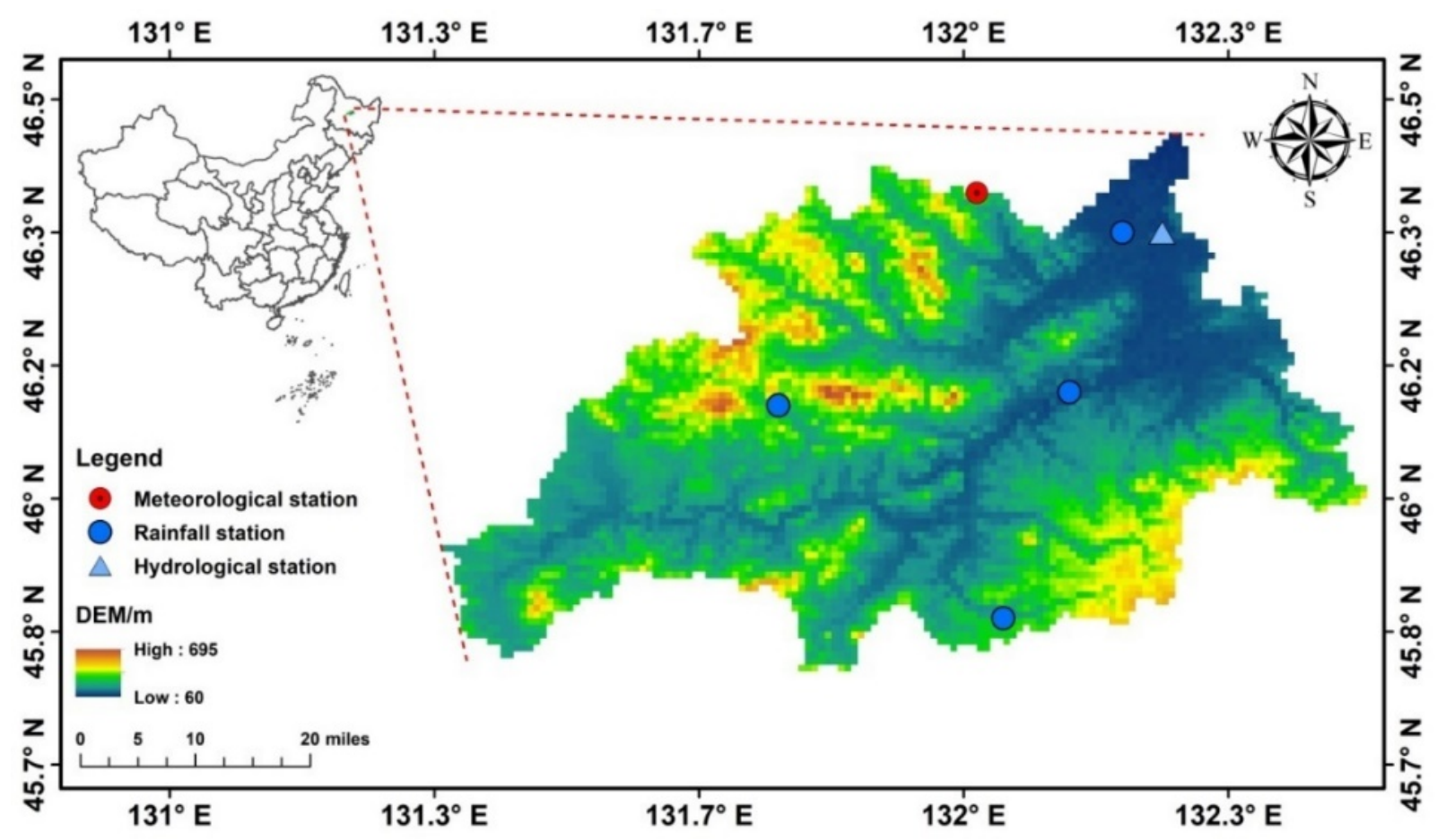

Figure 1. The location of the study area.

In the 1950s and 1970s, China invested a large amount of manpower to carry out largescale reclamation of wasteland in the Naoli River Basin, which led to a large expansion to the area of cultivated land. Although the expansion of arable land may promote the development of agriculture, it may also aggravate the risk of ecological degradation. Therefore, within a certain range of the topography and slope, the return of farmland to grassland and forestland has been determined by law in China. In October 1998, the Central Committee of the Communist Party of China and the State Council on Post-disaster Reconstruction, Rehabilitation of Rivers and Lakes, and Water Conservancy approved several options, such as mountain closure measures, prioritizing conversion of farmland into forestland during post-disaster reconstruction, deforestation prohibition, and forest closure promotion, and over cultivated land was gradually converted into forestland [28]. In December 2002, to standardize the policy of returning farmland to forestland and to improve the quality and progress of projects, the State Council promulgated certain regulations on the return of farmland to forestland and grassland, bringing them under legal management [29]. In August 2007, the State Council issued a notice to complete the policy of returning farmland to forestland followed by regulations to ensure the protection of the rights and interests of farmers. Furthermore, the State Council supported decisions to extend the farmland policy subsidy term, enhance the building of basic grain crop farmland, transform sloped lands into terraced fields, and strengthen the construction of rural energy [30].

The Baoqing watershed is located in the upper reaches of the Naoli River in the southeastern part of the water system and covers an area of $3689 \mathrm{~km}^{2}$, which is the largest catchment area in the Naoli River system. The Baoqing Basin is categorized as having a humid to subhumid continental climate. Warm and rainy summers are typically followed by cold winters with a historical mean temperature and rainfall of $3.5^{\circ} \mathrm{C}$ and $518 \mathrm{~mm}$, respectively. The rainfall distribution pattern is uneven, and $72 \%$ of the precipitation occurs between June and September. The precipitation accounts for $44 \%$ of the annual rainfall in July and August. In this study, we focused on the catchment areas above the Baoqing station to investigate the effects of the return of farmland to forestland and grassland on the watershed runoff. 


\section{Data Sources and Research Methods}

\subsection{Data Sources}

A digital elevation model (DEM) was derived from the National Oceanic and Atmospheric Administration (NOAA) Data Center [31], with a spatial resolution of 30 inches. The obtained 10-day (three records per month) spot vegetation normalized difference vegetation index (NDVI) dataset was provided by the National Cryosphere Desert Data Center (NCDC) [32], and the source for this dataset is the Flemish Institute for Technological Research, Belgium (VITO) [33], with a spatial resolution of approximately 30 inches. The land cover was represented according to the International Geosphere-Biosphere Programme (IGBP) [34], at a spatial resolution of 30 inches, and the extracted data revealed a total of eight IGBP-based study basin land cover types. The area proportion of the eight land cover types are listed in Table 1, and the IGBP land cover spatial distribution map of the study watershed is shown in Figure 2. The soil data were provided by the Harmonized World Soil Database (HWSD) [35]. Meteorological data were obtained from the Baoqing station, while runoff and precipitation data were retrieved from China's Hydrological Yearbook, Heilongjiang River Basin Hydrological Data volume 1. There was a lack of measured flow data from early December to March and April due to the freezing and severing of rivers in winter. In this paper, any missing data were recorded as 0 . According to the data collected at rain-measuring and flow stations, the continuity of these two kinds of data is poor and can only be synchronized with meteorological data from 1997 to 2001.

Table 1. The area proportion of eight land cover types.

\begin{tabular}{ccc}
\hline No. & Land Cover Types & Area Proportion of Each Land Cover Type/\% \\
\hline 1 & Deciduous coniferous forests & 0.96 \\
2 & Deciduous broad-leaved forests & 10.60 \\
3 & Mixed forests & 45.75 \\
4 & Forests & 0.05 \\
5 & Grasslands & 5.55 \\
6 & Arable land & 36.42 \\
7 & Urban and built-up areas and & 0.05 \\
8 & cultivated land & 0.63 \\
\hline
\end{tabular}

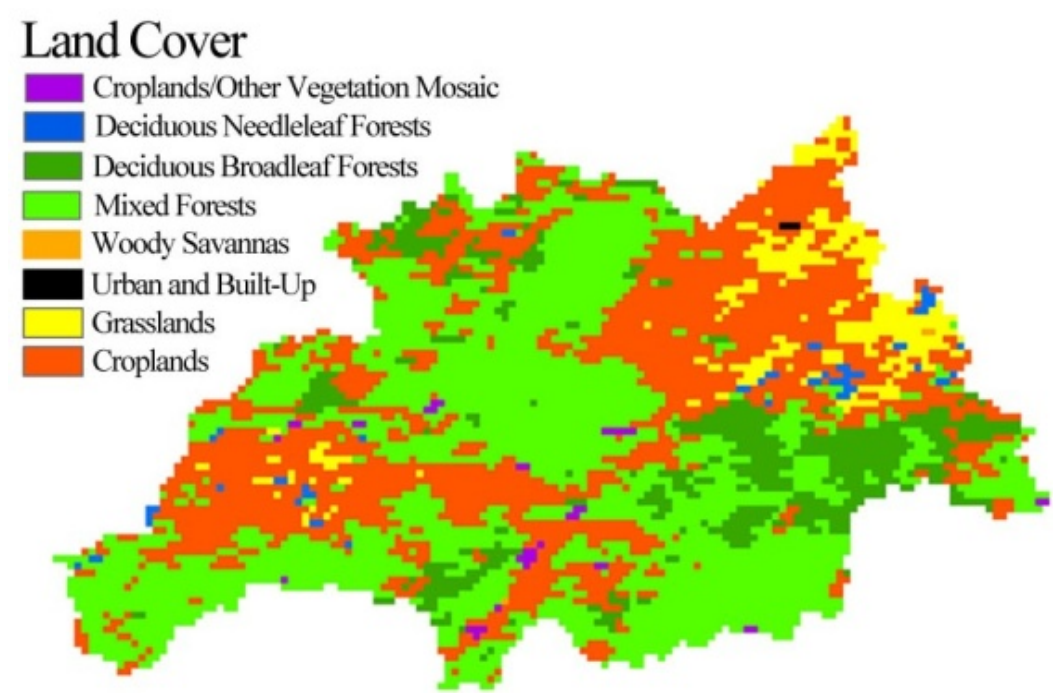

Figure 2. IGBP land cover spatial distribution map of the study watershed. 


\subsection{Model Method}

\subsubsection{Description of the Grid-Based Sacramento (GSAC) Model}

The GSAC model was adopted for the calculation of runoff, infiltration and evapotranspiration. The GSAC model calculates the spatiotemporal distribution of hydrological variables within a basin at a defined grid resolution. The GSAC model simulates canopy interception, snowfall and snowmelt and simplifies the components of actual evapotranspiration (ET) and runoff. HWSD data can be used to determine most of the parameters, and the remaining parameters can be determined by the algorithm. In general, the GSAC model can be driven using only DEM, land cover, NDVI, precipitation, and meteorological data, and the model does not have high input data requirements and can be used for the simulation of hydrological processes in cold areas [23]. The GSAC model was employed to simulate the flow process at the outlet section of the basin under cultivated land change, coupled with the regional ecological water demand problem. Table 2 lists the eleven parameters of the model.

Table 2. GSAC model parameters.

\begin{tabular}{ccc}
\hline No. & Parameter & Description \\
\hline 1 & UZTWM & The upper layer tension water capacity, mm \\
2 & UZFWM & $\begin{array}{c}\text { The upper layer free water capacity, mm } \\
\text { Interflow depletion rate from the upper layer free water } \\
\text { storage, }\end{array}$ \\
4 & UZK & The lower layer tension water capacity, mm \\
5 & LZTWM & Percolation fraction that goes directly to the lower layer \\
free water storage
\end{tabular}

\subsubsection{Calibration of The GSAC Model Parameters}

Free Search (FS) is a group-based optimization algorithm [36]. In this paper, the Nash-Sutcliffe model efficiency coefficient (NSEC) [37] was used as objective function for calibrating model parameters, with $0 \leq \mathrm{NSEC} \leq 1$ as the constraint condition, and FS was used to calibrate the parameters. Data from 1997 to 1999 were selected, and the parameters of the GSAC model were calibrated with the FS algorithm. Data from 2000 to 2001 were employed to validate the model simulations. The model was tested in regard to the suitability of the determined parameters (1997-2001) for the change in land cover conditions, minimum flow rate at the beginning of each year, and basin grid. The initial values of various variables such as the soil wilting point, water storage quantity, canopy interception volume, and two-layered free water storage were set to zero. The parameters of the GSAC model determined by the FS algorithm are listed in Table 3. According to the parameter calibration results, flow simulation results during the test and validation periods were obtained, as shown in Figures 3 and 4, respectively.

$$
N S E C=1-\frac{\sum_{i=1}^{n}\left(Q_{o b s, i}-Q_{s i m, i}\right)^{2}}{\sum_{i=1}^{n}\left(Q_{o b s, i}-\bar{Q}_{o b s}\right)^{2}}
$$


where NSEC is the efficiency coefficient of the Nash-Sutcliffe model; $Q_{o b s, i}$ is the measured flow on day $i, \mathrm{~m}^{3} \cdot \mathrm{s}^{-1} ; Q_{\text {sim }, i}$ is the simulated flow on day $i, \mathrm{~m}^{3} \cdot \mathrm{s}^{-1} ;$ is the mean value of the measured flow series, $\mathrm{m}^{3} \cdot \mathrm{s}^{-1}$.

Table 3. Parameter calibration results of the GSAC model.

\begin{tabular}{|c|c|c|c|c|c|}
\hline Parameter & Unit & Description & $\begin{array}{l}\text { Lower } \\
\text { Limit }\end{array}$ & $\begin{array}{l}\text { Upper } \\
\text { Limit }\end{array}$ & Value \\
\hline$P_{\text {Zup }}$ & $\mathrm{N} / \mathrm{A}$ & $Z_{\text {up }}$ adjustment coefficient & 0 & 5 & 4.2923 \\
\hline$P_{\text {UZTWM }}$ & $\mathrm{N} / \mathrm{A}$ & UZTWM adjustment coefficient & 0.70 & 1.30 & 1.0331 \\
\hline$P_{\text {UZFWM }}$ & $\mathrm{N} / \mathrm{A}$ & UZFWM adjustment coefficient & 0.70 & 1.30 & 0.9847 \\
\hline$P_{U Z K}$ & $\mathrm{~N} / \mathrm{A}$ & UZK adjustment coefficient & 0.70 & 1.30 & 0.9180 \\
\hline$P_{\text {LZTWM }}$ & $\mathrm{N} / \mathrm{A}$ & LZTWM adjustment coefficient & 0.70 & 1.30 & 1.2536 \\
\hline$P_{\text {PFREE }}$ & $\mathrm{N} / \mathrm{A}$ & PFREE adjustment coefficient & 0.70 & 1.30 & 0.8117 \\
\hline$P_{\text {LZFSM }}$ & $\mathrm{N} / \mathrm{A}$ & LZFSM adjustment coefficient & 0.70 & 1.30 & 1.1171 \\
\hline$P_{L Z F P M}$ & $\mathrm{~N} / \mathrm{A}$ & LZFPM adjustment coefficient & 0.70 & 1.30 & 0.8092 \\
\hline$P_{\text {LZSK }}$ & $\mathrm{N} / \mathrm{A}$ & LZSK adjustment coefficient & 0.70 & 1.30 & 1.0234 \\
\hline$P_{\text {LZPK }}$ & $\mathrm{N} / \mathrm{A}$ & LZPK adjustment coefficient & 0.70 & 1.30 & 0.9808 \\
\hline$P_{\text {REXP }}$ & $\mathrm{N} / \mathrm{A}$ & REXP adjustment coefficient & 0.70 & 1.30 & 1.0821 \\
\hline$P_{\text {ZPERC }}$ & $\mathrm{N} / \mathrm{A}$ & ZPERC adjustment coefficient & 0.70 & 1.30 & 1.0232 \\
\hline$T_{s r}$ & ${ }^{\circ} \mathrm{C}$ & Air temperature threshold & -10 & 10 & 2.9942 \\
\hline$M_{f}$ & $\begin{array}{c}\mathrm{mm}^{\circ} \mathrm{C}^{-1} \\
\text { day }^{-1}\end{array}$ & Degree-day factor & 0 & 12 & 2.5245 \\
\hline$C I$ & $\mathrm{~N} / \mathrm{A}$ & $\begin{array}{c}\text { Interflow storage recession } \\
\text { coefficient }\end{array}$ & 0 & 1 & 0.8145 \\
\hline$C B$ & $\mathrm{~N} / \mathrm{A}$ & $\begin{array}{c}\text { Base flow storage recession } \\
\text { coefficient }\end{array}$ & 0 & 1 & 0.9457 \\
\hline K & $\mathrm{N} / \mathrm{A}$ & $\begin{array}{l}\text { Muskingum method storage } \\
\text { coefficient }\end{array}$ & 0 & 24 & 22.3690 \\
\hline$x$ & $\mathrm{~N} / \mathrm{A}$ & $\begin{array}{l}\text { Muskingum method weighting } \\
\text { factor }\end{array}$ & 0 & 0.5 & 0.0150 \\
\hline
\end{tabular}

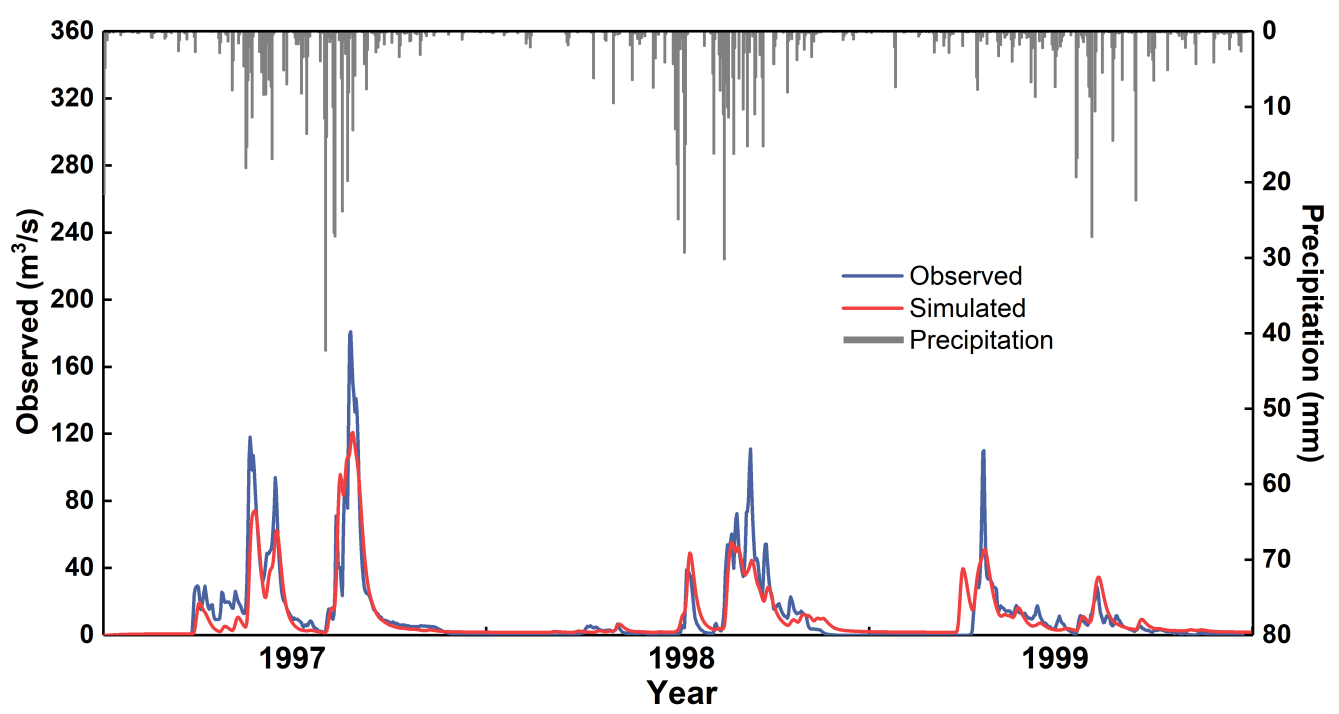

Figure 3. Baoqing station flow simulation results during the calibration period (1997-1999). 


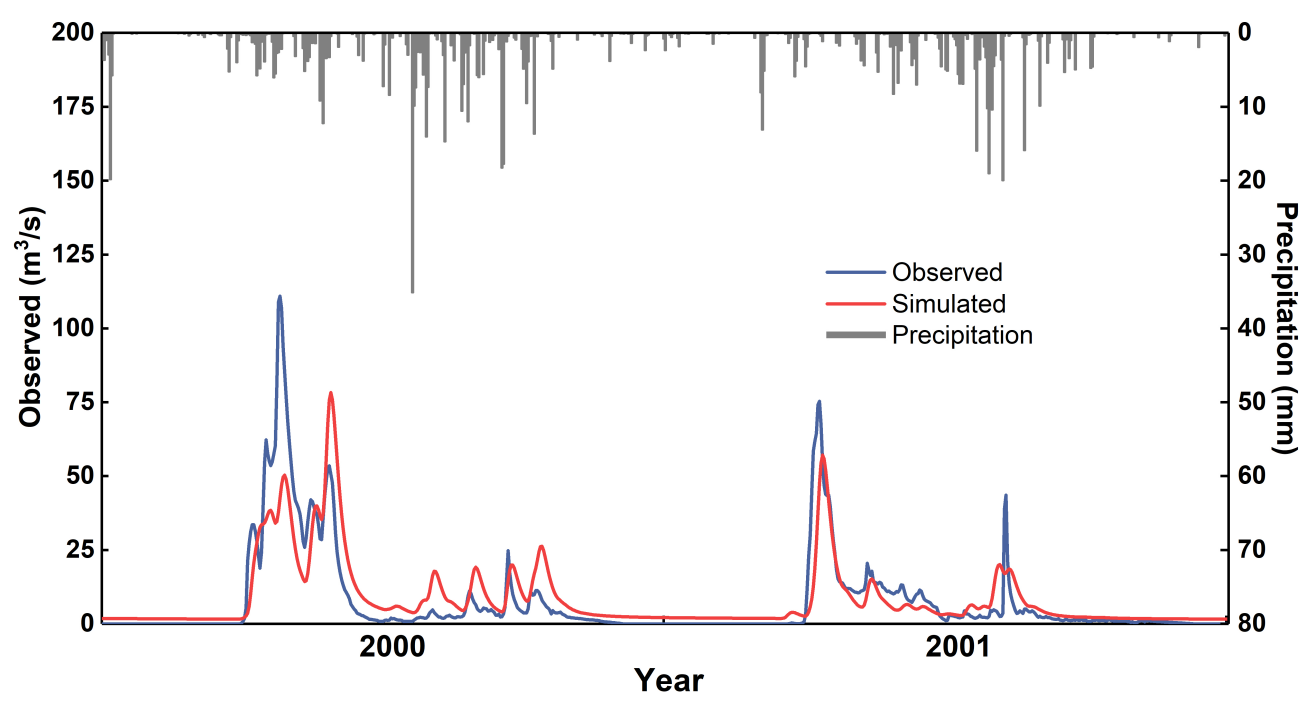

Figure 4. Baoqing station flow simulation results during the validation period (2000-2001).

Figures 3 and 4 show the simulated flow results, which are in good agreement with the flow observations. NSEC values of the test and validation periods were calculated, and the NSEC values of the test period from 1997 to 1999 were $0.8086,0.7607$, and 0.5564 , and the NSEC values of the validation period from 2000 to 2001 were 0.6416 and 0.6826 . According to the Standard of Hydrological Information and Forecasts issued by the Ministry of Water Resources of China, the simulation accuracy of the 1997 and 1998 models is class b and that of the other 3-year models is class c, which suitably reproduces the measured flow process in the section of the Baoqing station. Referring to the model parameterization results (Figures 3 and 4), the GSAC model can be used to study the response of the outlet section discharge to the cultivated land change in the Baoqing watershed.

\section{Runoff Simulation Analysis under Farmland Change}

\subsection{Scenario Setting of Farmland Change}

Deciduous coniferous forests and grasslands occupy a small proportion of the area in the research basin. Therefore, when setting the scenarios of the return of farmland to forestland and grassland, only part of the cultivated land is considered to be converted into these two types of land cover. The slope range of the farmland returned to forestland in Heilongiang Province is between $15^{\circ}$ and $25^{\circ}$. For example, it has been stipulated in certain documents that the return of farmland to forestland in Heilongjiang Province mainly focuses on steeply sloping farmland with a slope larger than $25^{\circ}$, sloping farmland with serious soil erosion and an important ecological status, and farmland with severe desertification. The Hengshan District in Jixi City focuses on the conversion of farmland into forestland with wasteland prioritized and half of the mountainous area and steeply sloping farmland with a slope larger than $15^{\circ}$. Hulin city plans to return $1153 \mathrm{mu}$ of sloping farmland with a slope above $15^{\circ}$ to forestland during the 12th five-year plan period. Referring to the considered slope in these areas, this paper chooses cultivated land with a slope ranging from $15^{\circ}$ to $25^{\circ}$ as the research object of the land cover change simulations, and a total of eight land cover change scenarios (please refer to Table 4 and Figure 5) are designed.

Table 4. Eight land cover change scenarios.

\begin{tabular}{cc}
\hline Change & Description of Land Cover/Change Scenarios \\
\hline Scenario 0 & The actual land cover situation and its spatial distribution \\
Scenario 1 & The cultivated land with a slope above $15^{\circ}$ is returned to grassland \\
Scenario 2 & The cultivated deciduous coniferous forest with a slope above $15^{\circ}$ \\
Scenario 3 & The cultivated land with a slope above $25^{\circ}$ is returned to grassland \\
\hline
\end{tabular}


Table 4. Cont.

\begin{tabular}{cc}
\hline Change & Description of Land Cover/Change Scenarios \\
\hline Scenario 4 & $\begin{array}{r}\text { The cultivated deciduous coniferous forest with a slope above } 25^{\circ} \\
\text { The cultivated land with a slope between } 15^{\circ} \text { and } 25^{\circ} \text { is returned to } \\
\text { grassland, while cultivated land with a slope above } 25^{\circ} \text { is returned to } \\
\text { deciduous coniferous forest }\end{array}$ \\
$\begin{array}{c}\text { Scenario 5 } \\
\text { Scenario 6 }\end{array}$ & $\begin{array}{c}\text { All the arable land is returned to grassland } \\
\text { Scenario 7 }\end{array}$ \\
\hline
\end{tabular}

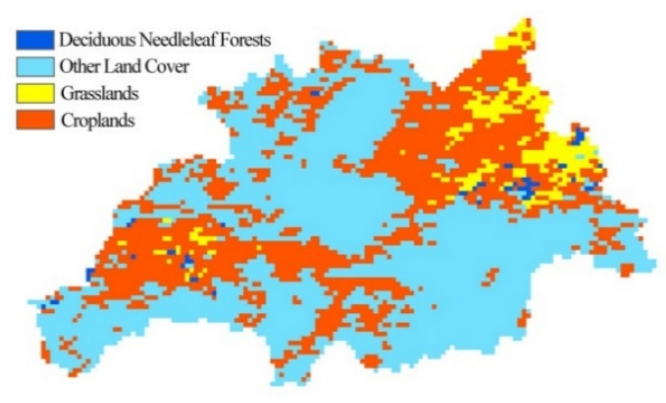

(a)

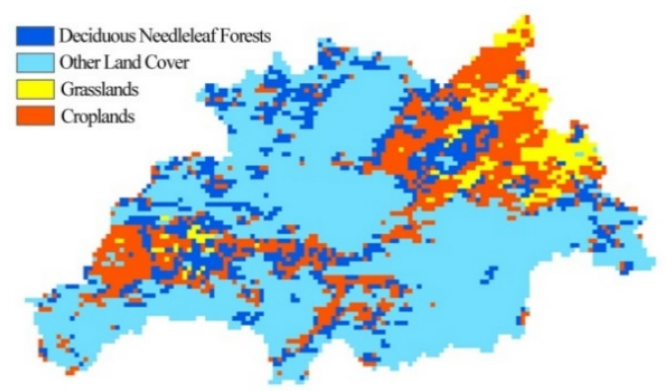

(c)

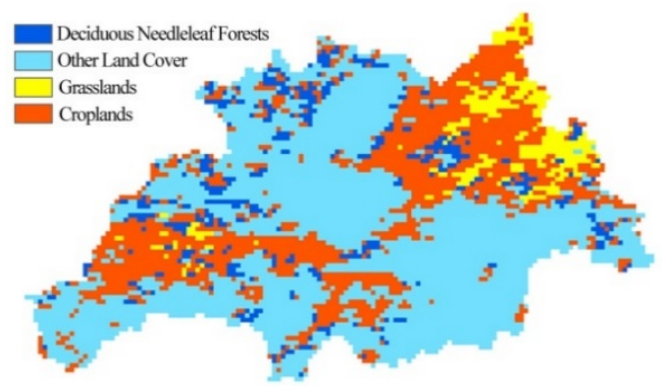

(e)

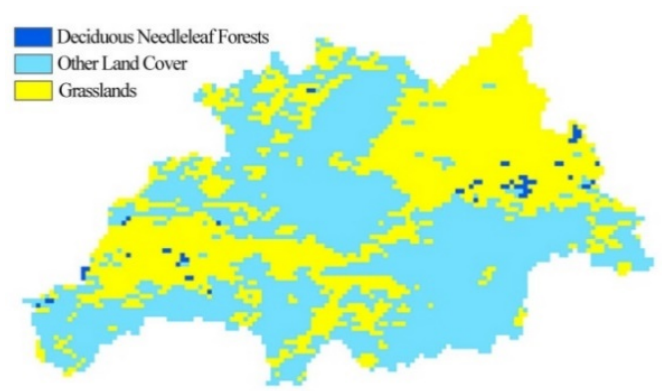

(g)

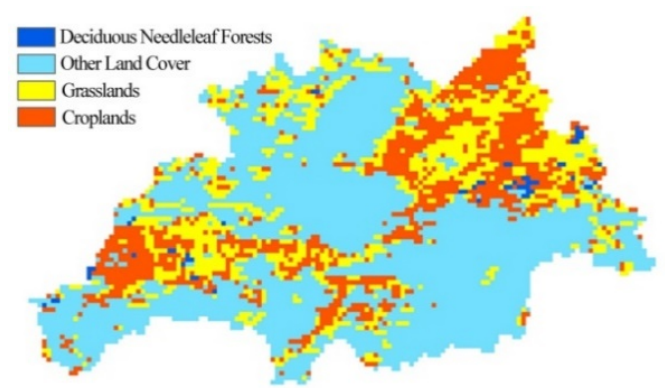

(b)

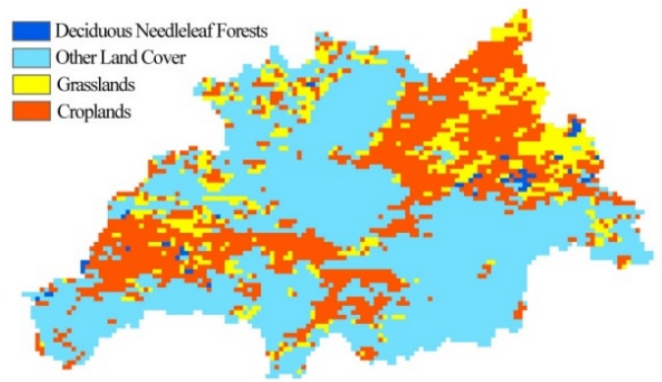

(d)

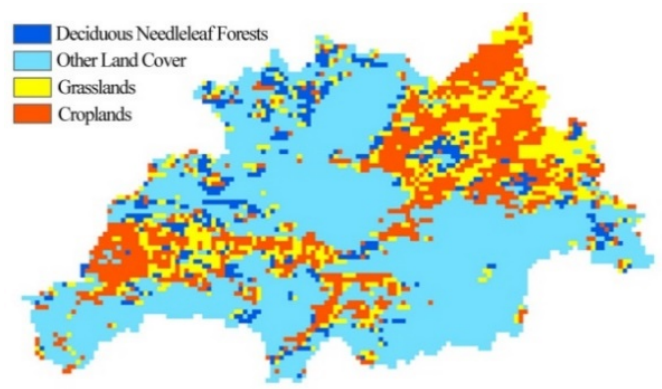

(f)

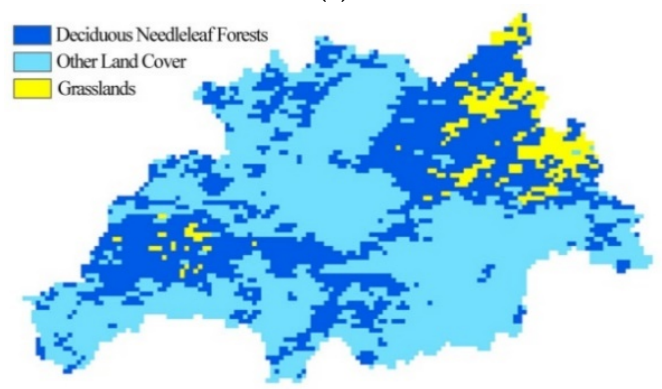

(h)

Figure 5. Simulation scenarios of cultivated land change for (a) scenario 0, (b) scenario 1, (c) scenario 2, (d) scenario 3 , (e) scenario 4, (f) scenario 5, (g) scenario 6, and (h) scenario 7. 


\subsection{Runoff Simulations under the Various Land Use/Cover Change Scenarios}

The GSAC model was applied to simulate the runoff in different years under the various scenarios, and the results are listed in Table 5 and shown in Figure 6.

Table 5. Baoqing station flow simulation results under the different land cover change scenarios; unit: $10^{8} \mathrm{~m}^{3}$.

\begin{tabular}{ccccccc}
\hline Change Scenarios & $\mathbf{1 9 9 7}$ & $\mathbf{1 9 9 8}$ & $\mathbf{1 9 9 9}$ & $\mathbf{2 0 0 0}$ & $\mathbf{2 0 0 1}$ & Average \\
\hline Scenario 0 & 4.792 & 2.897 & 2.521 & 3.581 & 1.822 & 3.123 \\
Scenario 1 & 5.481 & 4.020 & 3.336 & 4.573 & 2.704 & 4.023 \\
Scenario 2 & 5.091 & 3.443 & 2.831 & 3.945 & 2.219 & 3.506 \\
Scenario 3 & 5.086 & 3.375 & 2.873 & 4.000 & 2.197 & 3.506 \\
Scenario 4 & 4.916 & 3.123 & 2.651 & 3.728 & 1.987 & 3.281 \\
Scenario 5 & 5.310 & 3.769 & 3.113 & 4.301 & 2.494 & 3.797 \\
Scenario 6 & 6.267 & 5.391 & 4.295 & 5.837 & 3.825 & 5.123 \\
Scenario 7 & 5.432 & 4.134 & 3.230 & 4.431 & 2.743 & 3.994 \\
\hline
\end{tabular}

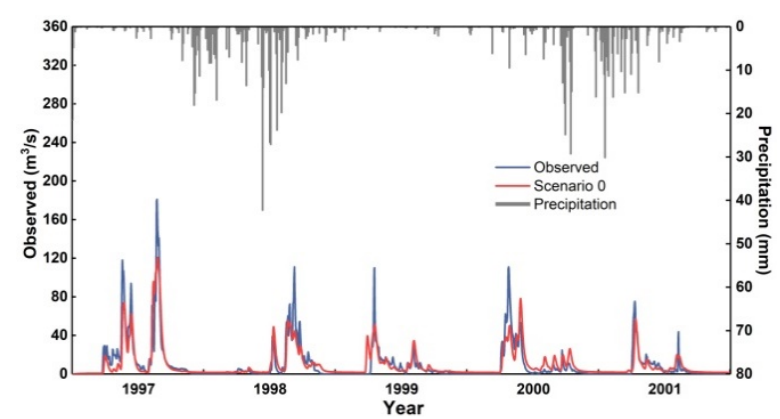

(a)

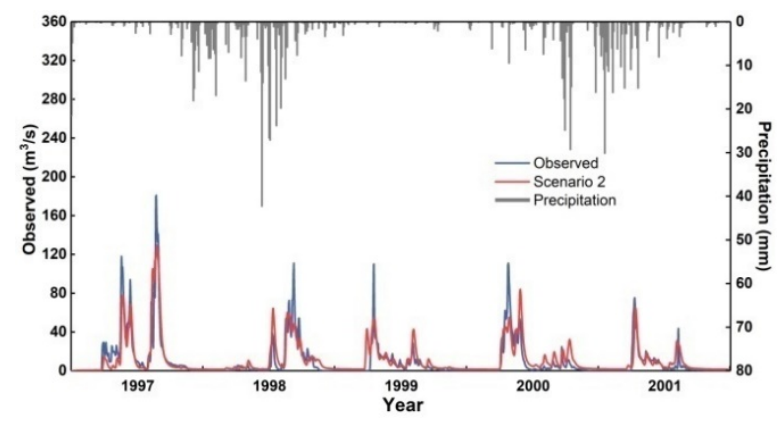

(c)

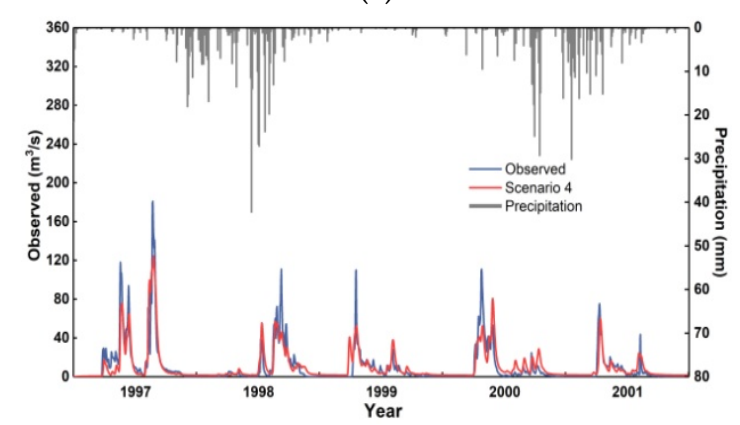

(e)

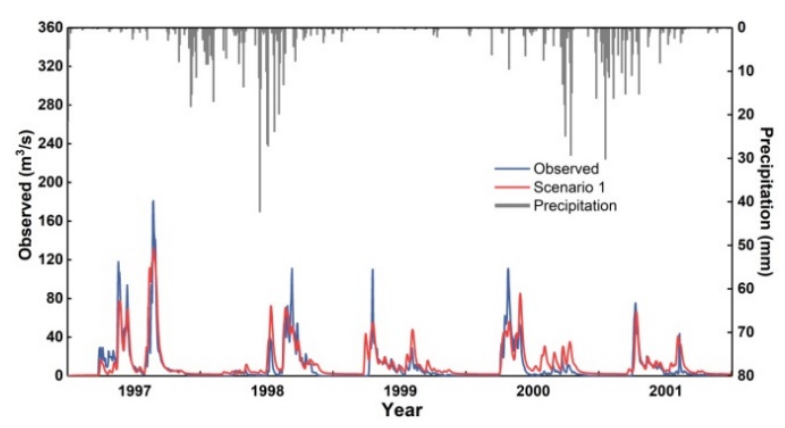

(b)

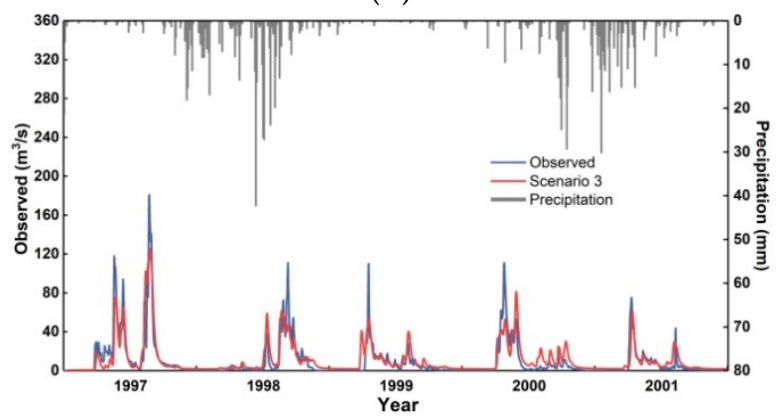

(d)

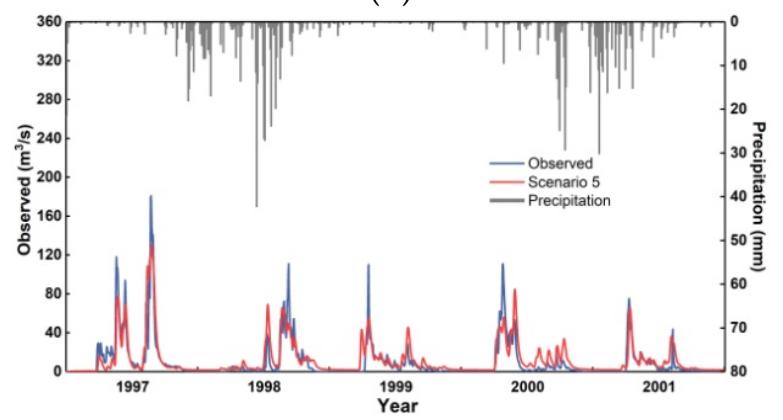

(f)

Figure 6. Cont. 


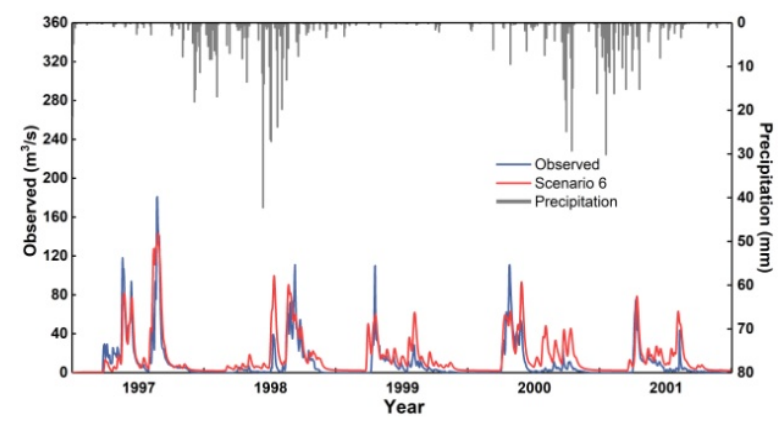

(g)

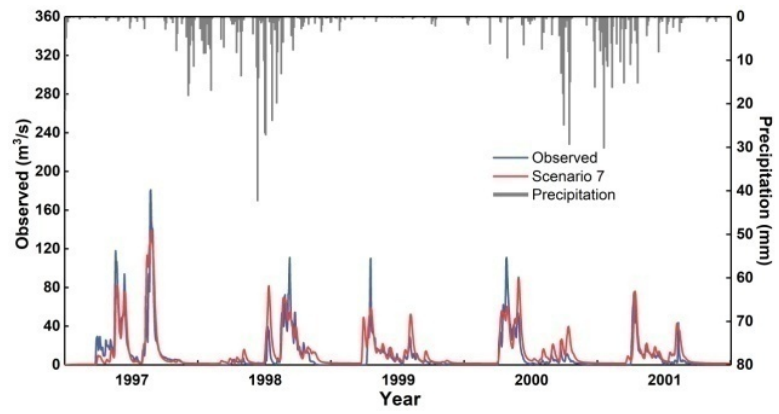

(h)

Figure 6. Flow simulation comparison diagram of the Baoqing station under cultivated land change for (a) scenario 0 , (b) scenario 1, (c) scenario 2, (d) scenario 3, (e) scenario 4, (f) scenario 5, (g) scenario 6, and (h) scenario 7.

Figure 6 shows the different simulated daily flow dynamics (1997 to 2001) under the various cultivated land change scenarios. The annual runoff under various scenarios (Table 5) varies greatly. Compared with the control "scenario 0 ", the annual runoff of scenarios 1-7 showed an increasing trend, within a range of 5.07-64.05\%. Among them, the growth under scenario 6 involving the conversion of all arable land into grassland was the largest, followed by scenario 1 involving the return of arable land with a slope larger than $15^{\circ}$ to grassland, and the smallest increase occurred under scenario 4 involving the return of cultivated land with a slope larger than $25^{\circ}$ to deciduous coniferous forest.

Through the runoff simulations in the Baoqing River Basin, it is found that for the same area of farmland returned to grassland, the flow rate increase caused by the return of farmland to grassland is larger than that caused by the return of farmland to forestland. From the perspective of the watershed topography, the smaller the slope of the farmland returned to grassland or forestland is, the higher the flow rate in the outlet section of the watershed. This occurs because more cultivated land is replaced by grassland or deciduous coniferous forest when a small slope is chosen.

\subsection{Land Use/Cover Mode Suitable for the Development of Watershed Water Resources}

According to Section 4.2, scenario 6 demonstrates the greatest influence on runoff. However, it is unlikely that this river basin will become a major Chinese grain-producing area. Cultivated land is expected to remain the main land use/cover in this region, based on the real practice of societal production. Considering the actual human production and life needs, cultivated land, as a kind of basic production resource, should not be completely converted into other land cover types. Hence, scenario 6 in this article, under the given numerical simulation conditions, only has a certain reference function. Under the conditions of following the national policies and regulations on the return of farmland to forestland and grassland, scenario 1 represents a desirable land-use model promoting runoff increase in this river basin. When the other land use/cover patterns remain unchanged, reducing the cultivated land area and increasing the grassland area could not only facilitate the development of water resources in the watershed but could also play a corresponding role in improving the local ecological environment and facilitating the development of animal husbandry. The suitable land use/cover patterns for the development of water resources in the basin are summarized in Table 6. 
Table 6. Land cover types suitable for the development of water resources.

\begin{tabular}{ccc}
\hline Land Cover Code & Name of the Land Cover & Proportion of the Basin Area/\% \\
\hline 3 & Deciduous needle leaf forests & 0.96 \\
4 & Deciduous broad leaf forests & 10.60 \\
5 & Mixed forests & 45.75 \\
8 & Woody savannas & 0.05 \\
10 & Grasslands & 20.26 \\
12 & Croplands & 21.70 \\
13 & Urban and built-up areas & 0.05 \\
14 & Croplands/other areas with & 0.63 \\
\end{tabular}

\subsection{Land Use/Cover Mode Applicable to the Ecological Water Demand}

The ecological environmental water demand of the watershed needs to be determined, and the R2Cross method and Tennant method are usually used. While the R2Cross method [38] is based on the Manning equation, the Tennant method [39] takes the percentage of predetermined average annual discharge as the recommended river discharge, which is suitable for areas with a lack of ecological data [36]. Both calculations show that there is excellent condition for aquatic life growth when the flow reaches $30 \%$ of the average annual flow.

The discharge results during the dry season simulated with grid and the distributed hydrological model in cold regions under the different land cover change scenarios are summarized in Table 7. For convenience, the measured discharge during the dry season is included in the table.

Table 7. Baoqing station flow under the different land cover change scene simulation scenarios; unit: $\mathrm{m}^{3} / \mathrm{s}$.

\begin{tabular}{ccccccccc}
\hline $\begin{array}{c}\text { Change } \\
\text { Scenarios }\end{array}$ & Measured & Scenario 1 & Scenario 2 & Scenario 3 & Scenario 4 & Scenario 5 & Scenario 6 & Scenario 7 \\
\hline $\begin{array}{c}\text { Average } \\
\text { flow rate }\end{array}$ & 0.62 & 0.81 & 0.69 & 0.72 & 0.68 & 0.77 & 0.96 & 0.73 \\
\hline
\end{tabular}

Similar to the changes in the trend of the annual runoff, the flow under the various simulation scenarios is higher than the measured flow during the dry season, where the corresponding flows under both simulation scenarios 1 (returning farmland with a slope exceeding $15^{\circ}$ to grassland) and 6 (converting farmland into grassland) exceed the ecological water demand estimated by the Tennant method $(30 \%)$. Considering that scenario 6 only represents a simulation, it is difficult to realize in reality. Therefore, the land cover conditions represented by scenario 1 are more suitable for the ecological water demand development requirements of the Baoqing River Basin.

In summary, scenario 1 is not only in line with the development of water resources in this basin but also meets the ecological water demand of this basin. Therefore, scenario 1 is determined to be the appropriate land use/cover mode in this region.

\section{Discussion}

The influence of land use/cover on runoff in different regions showed different results. Li Jia et al. studied the impact of land use/land cover scenario changes on runoff in the source region of the Yangtze River [40], the result showed runoff decreased 16.7\% under the situation of forest and grass land covering the whole area of the basin; runoff increased $16.1 \%$ when the forest and grass land area changed into sand land and bare land; runoff increased $28.4 \%$ when there were no forest and grass land; runoff increased $5.6 \%$ when forest and grass land grew perfectly. Increase of forestland and grassland made the runoff decrease and the increase of sand and bare land led to a rise of runoff. 
Jia Jing and Shi Xiaoli took Qinhuangdao area as an example to discuss the impact of land use/cover change on regional runoff [41], and the results show that the rapid increase of cultivated land and the decrease of forest and bare land resulted in the increase of annual average runoff by $4.79 \%$; the increase of forest land and the decrease of cultivated land and bare land resulted in a decrease of the average annual runoff by $3.32 \%$; the urban construction land increased significantly, and the cultivated land and forest decreased, resulting in an average annual runoff increase of $2.62 \%$. The increase of cultivated land and urban construction land can increase the runoff to different degrees, while the forest land can conserve water and reduce the runoff.

The study results of this paper show that the return of cultivated land to grassland on slopes steeper than $15^{\circ}$ leads to an increase of the average annual runoff by $29 \%$; the cultivated land being returned to deciduous coniferous forest on slopes steeper than $15^{\circ}$ results in an increase of average runoff over the years by $12 \%$; the cultivated land on slopes steeper than $25^{\circ}$ being returned to grassland causes an increase in average runoff over the years by $12 \%$; the cultivated land on slopes steeper than $25^{\circ}$ being returned to deciduous coniferous forest results in an increase in average runoff over the years by $5 \%$; the cultivated land on slopes between $15^{\circ}$ and $25^{\circ}$ being returned to grassland, and the cultivated land with on slopes over $25^{\circ}$ being returned to deciduous coniferous forest both result in an increase of average runoff over the years by $22 \%$; the cultivated land being completely changed into grassland results in an increase of average runoff over the years by $64 \%$; the cultivated land being completely changed into coniferous forest causes an increase of average runoff over the years by $28 \%$.

According to the simulation results, the increase of the area of farmland converted to forest and grassland in the study area leads to an increase of the average runoff over the years, which is contrary to the data in other study areas. The reason may be that the evapotranspiration of cultivated land in the study area is greater than that of grassland and woodland.

\section{Conclusions}

The parameters of the GSAC model are calibrated via the simulation of the flow process in the cold and important Baoqing River Basin. During the calibration period from 1997 to 1999 , the NSEC values were $0.8086,0.7607$, and 0.5564 , and during the validation period from 2000 to 2001, the NSEC values were 0.6416 and 0.6826 . The simulation precision is high, and the daily flow process from 1997 to 2001 in the river basin is suitably reproduced. The GSAC model reveals a good applicability in this watershed.

The conversion of cultivated land into grassland could cause an increase in the annual runoff over the control situation. The increase ranges between 5.07 and $64.05 \%$, and the flow rate under the scenario involving the conversion into grassland is high. The influence of grassland and forestland and the watershed outlet runoff distribution shows a negative correlation between the slope and discharge. The lower the gradient threshold of returning arable land to forest or grassland, the more arable land will be replaced by grassland or deciduous coniferous forest, resulting in more water production in the watershed.

There is a large difference in the average annual runoff among the various simulation scenarios. For the same area in the Baoqing River Basin, the conversion of farmland into grassland imposes a greater impact on the flow rate than does the conversion of farmland into forestland. A comparison of the scenarios indicates that the average annual runoff simulated under scenario 6 is the highest. Considering its practical significance, scenario 1 represents the appropriate land use mode to increase the runoff in the river basin under the conditions of following the national policies and regulations on the return of farmland to forestland and grassland. When the other land use/cover patterns remain unchanged, reducing the cultivated land area and increasing the grassland area are not only conducive to the development of water resources in the watershed but also play a corresponding role in improving the local ecological environment and facilitating the development of animal husbandry. 
The GSAC hydrological model was applied to simulate the runoff under different LUCC scenarios, and the flow during the dry season at the Baoqing station was determined. The results show that the average annual discharge of the watershed after the conversion of cultivated land to grassland with slopes steeper than $15^{\circ}$ could meet the ecological water demand of the region and the actual demand of cultivated land area for stable crop yield in the study area. This result has some guiding significance for the rational planning of land use pattern in the alpine watershed.

Author Contributions: Conceptualization, X.B.; methodology, X.B.; software, B.W.; validation, B.W.; formal analysis, Y.Q.; investigation, Y.Q.; resources, Y.Q.; data curation, B.W.; writing—original draft preparation, X.B.; writing-review and editing, B.W.; funding acquisition, Y.Q. All authors have read and agreed to the published version of the manuscript.

Funding: This research was funded by the Heilongjiang Provincial Postdoctoral Funding Project (LBH-Z18264) and Key Laboratory for Efficient Utilization of Agricultural Water Resources, Department of Agriculture and Rural Affairs, Northeast Agricultural University (No. 2015001 and 2015003).

Institutional Review Board Statement: Not applicable.

Informed Consent Statement: Not applicable.

Data Availability Statement: The data used in this article are from the following publicly accessible repositories: 1. A digital elevation model (DEM) was derived from the National Oceanic and Atmospheric Administration (NOAA) Data Center. Available online: https://www.noaa.gov/ (accessed on 10 December 2020) reference number [31]. 2. The obtained 10-day (three records per month) spot vegetation normalized difference vegetation index (NDVI) dataset was provided by the National Cryosphere Desert Data Center (NCDC). Available online: http:/ /www.ncdc.ac.cn/portal/ (accessed on 10 December 2020) reference number [32]. 3. The source for this dataset is the Flemish Institute for Technological Research, Belgium (VITO). Available online: https:/ / vito.be/en/research (accessed on 10 December 2020) reference number [33]. 4. The land cover was represented according to the International Geosphere-Biosphere Programme (IGBP). Available online: http:/ / www.igbp. net/ (accessed on 10 December 2020) reference number [34]. 5. The soil data were provided by the Harmonized World Soil Database (HWSD). Available online: http://www.fao:soils--portal/ soil-survey/soil-maps-and-databases/en/ (accessed on 10 December 2020) reference number [35]. 6. Meteorological data were obtained from the Baoqing station, while runoff and precipitation data were retrieved from China Hydrological Yearbook, Heilongjiang River Basin Hydrological Data volume 1.

Conflicts of Interest: The authors declare no conflict of interest.

\section{References}

1. Liu, T. Research of Land Use Change and Its Regional Temperature Effect Simulation in Agroforestry Ecotone of Northeast; Northeast Institute of Geography and Agroecology, Chinese Academy of Sciences: Jilin, China, 2012.

2. Zhai, J.; Shao, Q.; Liu, J. Impact analysis of climate change from land use/cover change in inner Mongolia Plateau. J. Nat. Resour. 2014, 29, 967-978. [CrossRef]

3. Zhu, Y.; Zhang, Q.; Zhou, X. Research on the impacts of land use/cover change on regional climate. Anhui Agric. Sci. Bull. 2012, 18, 76-78. [CrossRef]

4. Zhang, R.; Pu, L.; Liu, Z. Advances in research on atmospheric environment effects of land use and land cover change. Areal Res. Dev. 2013, 32, 123-128. [CrossRef]

5. Sun, Q.; Tashpolat, T.; Ding, J.; Zhang, F.; Mamat, S.; Han, G. Study on land use/cover changes and soil salinization in dry areas: A case study of Shaya county in Xinjiang. Prog. Geogr. 2012, 31, 1212-1223. [CrossRef]

6. Zhu, L.; Xu, S.; Chen, P. Study on the impact of land use/land cover change on soil erosion in mountainous areas. Geogr. Res. 2003, 22, 432-438. [CrossRef]

7. Zeng, H.; Du, Z.; Yang, Y.; Li, X.; Zhang, Y. Effects of land cover change on soil organic carbon and light fraction organic carb on at river banks of Fuzhou urban area. Chin. J. Appl. Ecol. 2010, 21, 701-706. [CrossRef]

8. Shi, X.; Li, Y.; Zhao, K.; Zhang, G.; Zhang, D.; Zhu, H. Land use/cover change and its effects on hydrologic processes in Nuomin River basin. Bull. Soil Water Conserv. 2013, 33, 23-28. [CrossRef]

9. Shi, X.; Li, Y.; Yan, D.; Zhao, K. Advances in the impacts of watershed land use/cover change on hydrological processes. Res. Soil Water Conserv. 2013, 20, 301-308. 
10. Shi, X.; Yang, Z.; Yan, D.; Li, Y.; Yuan, Z. On hydrological response to land-use/cover change in Luanhe River basin. Adv. Water Sci. 2014, 25, 21-27. [CrossRef]

11. Wang, Y.; Zhang, L.; Wang, J. Response of the hydrological process to land-use/cover change in Taohe River basin. J. Glaciol. Geocryol. 2016, 38, 200-210.

12. Zhao, G.; Liu, J.; Kuang, W.; Ouyang, Z.; Xie, Z. Disturbance impacts of land use change on biodiversity conservation priority areas across China during 1990-2010. J. Geogr. Sci. 2015, 25, 515-529. [CrossRef]

13. Wu, J.; Lv, J. Effects of land use change on the biodiversity. Ecol. Environ. 2008, 17, 1276-1281. [CrossRef]

14. Kumar, S.; Merwade, V. Impact of watershed subdivision and soil data resolution on SWAT model calibration and parameter uncertainty. J. Am. Water Resour. Assoc. 2009, 45, 1179-1196. [CrossRef]

15. Pang, J.; Liu, C.; Xu, Z. Impact of land use change on runoff and sediment yield in the miyun reservoir catchment. J. Beijing Norm. Univ. Nat. Sci. 2010, 46, 290-299.

16. Xu, Z.; Chen, L. Progress on studies and applications of the distributed hydrological models. J. Hydraul. Eng. 2010, 41, 1009-1017. [CrossRef]

17. Freeze, R.; Harlan, R. Blueprint for a physically-based digitall hydrological response model. J. Hydrol. 1969, 9, 237-258. [CrossRef]

18. Onstad, C.; Jamieson, D. Modeling the effects of land use modifications on runoff. Water Resour. Res. 1970, 6, 1287-1295. [CrossRef]

19. Gary, W.; Carmen, D. Impacts of landuse changes on runoff generation in the east branch of the Brandywine Creek watershed using a GIS-based hydrologic model. Middle States Geogr. 2007, 40, 142-149.

20. Song, X.; Wang, B.; Du, L.; Shi, D. Effect of land use change on surface runoff in Lushan county. J. Henan Agric. Sci. 2008, 4, 57-60. [CrossRef]

21. Chaffari, G.; Keesstra, S.; Ghodousi, J.; Ahmadi, H. SWAT-simulated hudrological impact of land-use change in the Zanjanrood Basin, Northwest Iran. Hydrol. Process. 2010, 24, 73-89. [CrossRef]

22. Niu, Z.; Zhao, W.; Liu, J.; Chen, X. Study on impact from change of land-use and land-cover on runoff in Weihe River Basin in Gansu Province. Water Resour. Hydropower Eng. 2012, 43, 5-10. [CrossRef]

23. Wang, B.; Wang, G.; Huang, J.; Gong, X.; Sun, Y. Distributed hydrological model based on grid and its application to daily runoff simulation for high-cold region. J. Hydroelectr. Eng. 2013, 32, 36-42.

24. He, H. China gauging station network. Adv. Water Sci. 2010, 21, 460-465. [CrossRef]

25. Yin, F.; Guan, X.; He, Y. Density analysis and Adjustment direction of Hydrographic network in Heilongjiang Province. Water Resour. Hydropower Northeast China 2007, 25, 36-38.

26. Li, T. Geological characteristics and prospecting potential analysis of Guokuishan area in Baoqing country. Heilongiiang Land Resour. 2010, 6, 39-47.

27. Heilongjiang Naoli River National Nature Reserve. Available online: http:/ / www.shidicn.com/ (accessed on 17 May 2021).

28. The Sate Council. A Few Comments on Disaster Reconstruction, Remediation Arena and Water Conservation; State Council Bulletin of the People's Republic of China: Beijing, China, 1998.

29. Dong, J.; Wang, L. The State Council promulgated the "Returning Farmland to Forests Ordinance". Pratacult. Sci. 2003, 20, 40.

30. Zhu, D. Study on the Model of Conversion of Cropland to Forest and Grassland and Sustainable Development in the Loess Plateau; Lanzhou University: Lanzhou, China, 2008.

31. National Oceanic and Atmospheric Administration (NOAA). Available online: https://www.noaa.gov/ (accessed on 10 December 2020).

32. National Cryosphere Desert Data Center (NCDC). Available online: http:/ / www.ncdc.ac.cn/portal/ (accessed on 10 December 2020).

33. Flemish Institute of for Technological Research (VITO). Available online: https:/ /vito.be/en/research (accessed on 10 December 2020).

34. International Geosphere-Biosphere Programme (IGBP). Available online: http://www.igbp.net/ (accessed on 10 December 2020).

35. Harmonized World Soil Database (HWSD). Available online: http://www.fao:soils--portal/soil--survey/soil--maps--and-databases/en/ (accessed on 10 December 2020).

36. Penev, K.; Littlefair, G. Free Search-A comparative analysis. Inf. Sci. 2005, 172, 173-193. [CrossRef]

37. Nash, J.; Sutcliffe, J. River flow forecasting through conceptual models part I-A discussion of principles. J. Hydrol. 1970, 10, 282-290. [CrossRef]

38. Mosely, M. The effect of changing discharge on channal morphology and instream uses and in a braide river Ohau River, New Zealand. Water Resour. 1982, 18, 800-812. [CrossRef]

39. Tennant, D. Instream flow regiments for fish, wildlife, recreation and related environmental resources. In Proceedings of Symposium and Specility Conference on Instream Flow Needs II; Orshorn, J.F., Allman, C.H., Eds.; American Fisheries Society: Bethesda, MD, USA, 1976; pp. 359-373.

40. Jia, L.; Zhang, X.; Yang, Y. SWAT model of runoff study under different land use/land cover scenarios in source region of the Yangtze River. J. Soil Water Conserv. 2012, 19, 119-128.

41. Jia, J.; Shi, X. Impacts of land use/land cover change on the runoff of qinhuangdao area. Geogr. Geo Inf. Sci. 2017, 33, 108-114. [CrossRef] 